de Oliveira Leite, V. G., Aquino Florenciano, R. B., Gamarra Arguelho, E., \& do Nascimento Lima, T. (2021). Trap rebuilding by Myrmeleon brasiliensis larvae (Neuroptera: Myrmeleontidae) in response to flooding: the effect of body size. Revista de Biología Tropical, 69(4), 1224-1232. https://doi.org/10.15517/rbt.v69i4.44478

\title{
Trap rebuilding by Myrmeleon brasiliensis larvae (Neuroptera: Myrmeleontidae) in response to flooding: the effect of body size
}

Vitor Gabriel de Oliveira Leite'; (D) https://orcid.org/0000-0003-4104-3093

Raquel Braga Aquino Florenciano'; (D) https://orcid.org/0000-0001-9019-5398

Edihanne Gamarra Arguelho'; (D) https://orcid.org/0000-0002-4549-6762

Tatiane do Nascimento Lima1,2*; (iD http://orcid.org/0000-0002-0656-1170

1. Universidade Federal de Mato Grosso do Sul, Campus de Aquidauana, Biodiversity Studies Laboratory, Rua Oscar Trindade de Barros, Bairro da Serraria, Aquidauana, Mato Grosso do Sul, Brazil; vg454053@gmail.com, raquell. aquino12@gmail.com, edihanne.arguelho@ufms.br

2. Universidade Federal de Mato Grosso do Sul, Programa de Pós-Graduação em Recursos Naturais, Faculdade de Engenharias, Arquitetura e Urbanismo e Geografia, Cidade Universitária, Campo Grande, Mato Grosso do Sul, Brazil; tatianenlima@gmail.com (*Correspondence)

Received 19-V-2021. Corrected 20-X-2021. Accepted 10-XI-2021.

\section{ABSTRACT}

Introduction: Immature forms of the antlion Myrmeleon brasiliensis (Neuroptera, Myrmeleontidae) build traps in dry sandy soil to capture prey.

Objective: The aim of the present study was to investigate how the waterlogging of the soil due to rain affects the trap rebuilding and relocation behavior of $M$. brasiliensis of different sizes.

Methods: The study was conducted between July and December 2019. Larvae M. brasiliensis were observed and collected from a forest reserve in the municipality of Aquidauana in the state of Mato Grosso do Sul, Brazil. Results: In the natural environment, most larvae rebuilt their traps in the same location seven days after the simulation of rain, with a smaller diameter than that observed prior to the simulation of rain. In the laboratory, the movements of M. brasiliensis larvae and rebuilding of the traps after the waterlogging of the soil was affected by body size. Larger larvae moved more and were more likely to rebuild their traps.

Conclusions: The saturation of the soil affects the foraging of $M$. brasiliensis larvae, which are impeded from rebuilding their traps for a period. In situations of long periods of saturated soil, the mortality rate of the larvae is high and rebuilding of the traps occurs after the soil dries out, but with a smaller trap size. These data suggest that changes in the rainfall pattern can affect the population structure of $M$. brasiliensis larvae, with the selection of larger individuals in situations of more severe rains. In this process, the smaller larvae are more affected, as their foraging is impeded.

Key words: antlion; construction behaviour; foraging; Myrmeleontinae; rainfall.

Many organisms build traps to capture prey. This foraging strategy evolved independently in different groups, such as spiders and insects (Alcock, 1972; Hansell, 2007; Ruxton \& Hansell, 2007). Sit-and-wait foraging behavior involving trap building diminishes energy that would otherwise be spent in the active search for prey. However, energy is spent on the building and maintenance of the trap (Botz et al., 2003; Gotelli, 1993). Thus, environmental disturbances that cause the destruction of the trap generate greater energy expenditure for these organisms, which can affect their fitness (Lima \& Silva, 2017; Lucas, 1985). 
Immature forms of the family Myrmeleontidae (Neuroptera order), which are known as antlions, have trap-building behavior. Among species of the sub-family Myrmeleontinae, traps are built in a funnel shape in dry sandy soil (Triplehorn \& Johnson, 2005; Youthed \& Moran, 1969;). The three-dimensional architecture of the trap and the granulometry of the soil cause prey items (arthropods moving along the ground) to fall into the trap (Devetak et al., 2020; Humeau et al., 2015;). Larger traps enable the capture of both large and small prey items. Upon falling into the trap, the prey is directed to the bottom of the pit, where the larva awaits to attack with its long falciform mandibles (Heinrich \& Heinrich, 1984; Nonato \& Lima, 2011).

Trap size is proportional to the body size of the antlion larva and is positively related to the successful capture of prey items (Dias et al., 2006; Missirian et al., 2006). A larger trap diameter increases the abundance and size range of the prey, which is the main benefit of increasing the capturing surface of the trap. However, a larger pit requires greater energy expenditure for maintenance and rebuilding in cases of more severe damage (Burgess, 2009; Griffiths, 1985; Lima \& Silva, 2017; Lucas, 1985)

The destruction of antlion traps can occur due to the interference of neighboring larvae, which toss sand out of their funnels during the building and maintenance of their traps (Day \& Zalucki, 2000; Simberloff, 1978). Trap destruction can also occur due to environmental factors, such as wind and rain. In natural environments, some species, such as Myrmeleon brasiliensis, Myrmeleon immaculatus and Myrmeleon crudelis, build traps in locations protected from the direct action of rain, such as under plantlets or fallen tree trunks (Gotelli, 1993; Lima \& Faria, 2007), whereas other species, such as Cueta lineosa and Morter obscurus, prefer open areas exposed to direct sunlight and rain (Devetak et al., 2020; Griffiths, 1980). Independently of the selection of the trap building location, all traps are destroyed in situations of strong rains, which can affect development, as the larvae are impeded from foraging until the soil dries out again. In the Cerrado biome (savanna) of Brazil, M. brasiliensis larvae were found to wait approximately five days before rebuilding their traps after rainfall (Freire \& Lima, 2019).

Larvae of Myrmeleon brasiliensis (Návas, 1914) pass through three instars before the formation of the pupa for the emergence of the adults. The traps built by these larvae range from 9 to $35 \mathrm{~mm}$ in diameter (Missirian et al., 2006). Given this variation in trap size, costbenefit ratios associated with the rebuilding and relocation of a trap must vary as a function of body size and trap size. Larger larvae have a greater energy supply, due to a greater fat reserve. Thus, the hypothesis raised in this work is that larger larvae may bear the costs of relocating and rebuilding the traps (after disturbing their traps) more efficiently than smaller larvae. In this case, after a rain event, the larger larvae would be the first to rebuild their traps. The aim of the present study was to investigate how the waterlogging of the soil due to rain affects the building behavior and relocation of the traps of $M$. brasiliensis larvae of different sizes.

\section{MATERIALS AND METHODS}

This study was conducted in a Permanent Protection Area (1 $600000 \mathrm{~m}^{2}$ ) located in the municipality of Aquidauana in the state of Mato Gross do Sul, Brazil (20²6’36” S \& $\left.55^{\circ} 40^{\prime} 02^{\prime} \mathrm{W}\right)$. Mean annual temperature and rainfall in the area are approximately $26^{\circ} \mathrm{C}$ and $1250 \mathrm{~mm}$, respectively. Rains are concentrated between October and March and the monthly precipitation index diminishes considerably between May and September, reaching zero (Coutinho, 2000). The present study was conducted between July and December 2019 .

In the reserve, ten quadrants measuring 40 x $40 \mathrm{~cm}$ were established with a metric tape and string, separated by a distance of $1 \mathrm{~m}$. In each quadrant, the position of the antlion traps was marked with wooden stakes $(10 \times 1 \mathrm{~cm})$ and the diameter of the traps was measured. 
The occurrence of rain was simulated with the aid of a watering can, to observe the effect of waterlogging on the rebuilding of the $M$. brasiliensis traps. A total of $200 \mathrm{ml}$ of water were poured on each quadrant. This quantity of water was chosen for being sufficient to destroy the traps without forming a puddle. After the rain simulation, the traps were observed daily. The presence of traces of the larvae was observed for the construction of new traps. In this way, it was possible to follow the movement of the M. brasiliensis larvae. Seven days after the rain simulation, the rebuilding of the traps was observed, and the diameters of the rebuilt traps were measured. There was no occurrence of natural rain during this period.

In the second part of the study, two experiments were set up in the laboratory. For such, M. brasiliensis larvae were collected from their traps through visual searches and transported to the laboratory. In the first experiment, 60 larvae were measured for body size (from the head to the end of the abdomen, excluding the mandible) and individually placed into plastic recipients $(20 \mathrm{~cm}$ length $\times 15 \mathrm{~cm}$ width $\times 10$ $\mathrm{cm}$ height) containing $195 \mathrm{~g}$ of sand removed from the collection site. After $24 \mathrm{~h}$ (time given for all larvae to build traps), the diameter of the traps was measured, and the location of the larvae was marked. To evaluate the effects of waterlogging, the occurrence of rain was simulated. A total of $9 \mathrm{ml}$ of water were poured directly into the trap. Thus, the soil around the trap remained dry, enabling the movement of the larva. After seven days, observations were made of the rebuilding of the traps, trap size and whether the trap had been relocated within the plastic recipient.

In a second experiment, another 60 larvae were measured for body size (head to abdomen) and placed into plastic recipients $(20 \mathrm{~cm}$ length x $15 \mathrm{~cm}$ width $x 10 \mathrm{~cm}$ height) containing $195 \mathrm{~g}$ of sand removed from the collection site. As in the previous experiment, trap diameter was measured after $24 \mathrm{~h}$. Next, the effect of waterlogging of the soil after rain was observed. For such, $30 \mathrm{ml}$ was water were poured directly onto the trap, forming a puddle so that the larva became submerged. After seven days, the water was drained, and the recipients were placed to dry in a plant nursery. For 15 days, observations were made of the rebuilding of the traps, trap size and mortality.

Al measurements were performed with digital calipers (precision: $0.01 \mathrm{~mm}$ ). Trap size before and after the simulation of rain in the field and in the laboratory, experiment was compared using the paired t-test. Logistic regression was performed to determine the probability of the rebuilding of the trap after the waterlogging of the soil in relation to body size of the M. brasiliensis larvae as well as the probability of the relocation of the trap in relation to body size.

\section{RESULTS}

An average of six $M$. brasiliensis larvae (range: two to 11) were found in each quadrant demarcated in the natural environment prior to the rain simulation. After the rain simulation, an average of four larvae were found per quadrant. The rebuilding rate at the same site was 61 $\%$. The traps rebuilt after the rain were smaller (d.f. $=36, \mathrm{~T}=2.15, \mathrm{P}=0.03)$. Mean $( \pm$ standard deviation) trap size was $26.11( \pm 11.84)$ $\mathrm{mm}$ prior to the rain simulation and $22.55 \mathrm{(} \pm$ $10.50) \mathrm{mm}$ after the rain simulation.

In the first laboratory experiment, $75 \%$ of the $M$. brasiliensis larvae rebuilt their traps after the rain simulation, $11 \%$ of which rebuilt at the same site. Among those that relocated their traps, the mean distance from the original site was $55.35 \mathrm{~mm}$. The probability of relocation increased as a function of body size (d.f. $=$ $1, X^{2}=24.33, \mathrm{P}=0.01$ ). The probability of trap reconstruction also increased as a function of larva size (d.f. $=1, X^{2}=20.35, \mathrm{P}=0.01$ ) (Fig. 1A, Fig. 1B). Mean trap size was $25.83 \pm 8.94$ $\mathrm{mm}$ prior to rain simulation and $27.51 \pm 7.54$ $\mathrm{mm}$ after rain simulation. This difference was non-significant (d.f. $=44, \mathrm{~T}=-1.43, \mathrm{P}=0.15$ ).

In the second laboratory experiment, when the $M$. brasiliensis larvae spent seven days in inundated soil (all the sand was waterlogged), $67 \%$ (considering a total of 60 larvae) did not 

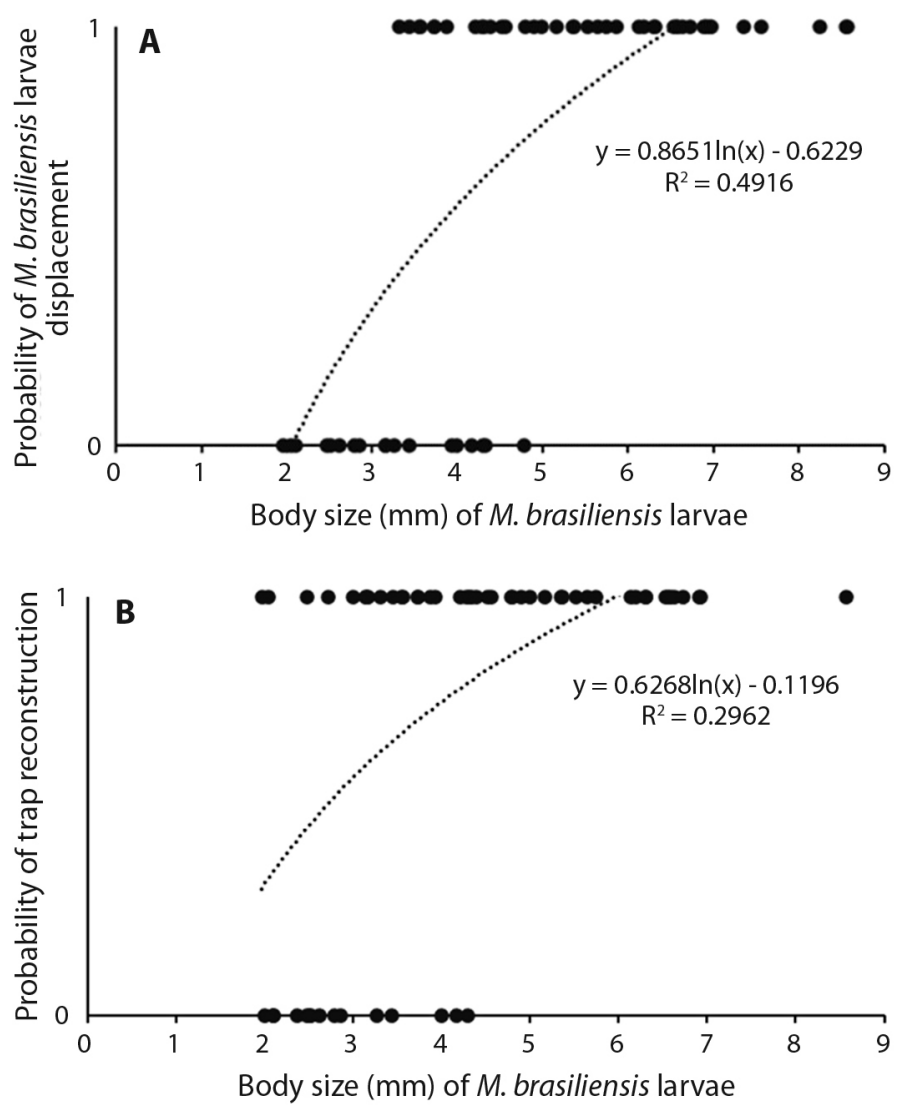

Fig. 1. A. Probability of displacement of M. brasiliensis larvae as function of body size after waterlogging of soil caused by simulation of rainfall. B. Probability of reconstruction of traps by $M$. brasiliensis larvae as function of body size after waterlogging of soil caused by simulation of rainfall (First Experiment).

rebuild their traps in the 15-day observation period after the draining of the water and drying of the soil. Among those that rebuilt, a significant reduction in trap size was found after the waterlogging of the soil (d.f. $=19, \mathrm{~T}=2.54$, $\mathrm{P}=0.01$ ). Mean trap size was $26.33 \pm 12.58$ $\mathrm{mm}$ before waterlogging and $21.88 \pm 6.68 \mathrm{~mm}$ after waterlogging.

The probability of reconstruction (d.f. $=1$, $\left.X^{2}=21.61, \mathrm{P}=0.01\right)$ and relocation the trap (d. f. $1=X^{2}=23.74, \mathrm{P}=0.01$ ) after a period of seven days in saturated soil increased as a function of body size (Fig. 2A, Fig. 2B). The mortality rate at the end of the experiment (seven days in saturated soil +15 days of observation) was $52 \%$. Some larvae were able to rebuild their traps when the soil dried but died in the subsequent days. Others died during the waterlogging period.

\section{DISCUSSION}

For trap-building insects, variables that cause the destruction of the trap should be considered during decisions regarding foraging behavior (Gotelli, 1993; Lima \& Lopes, 2016). The selection of an adequate site for building a trap is an important component of the foraging behavior of sit-and-wait predators, especially when movements are rare. The relocation and the rebuilding of a new trap in the absence of environmental disturbance rarely occur among antlions, possibility due to the metabolic cost associated with the rebuilding of the trap and 

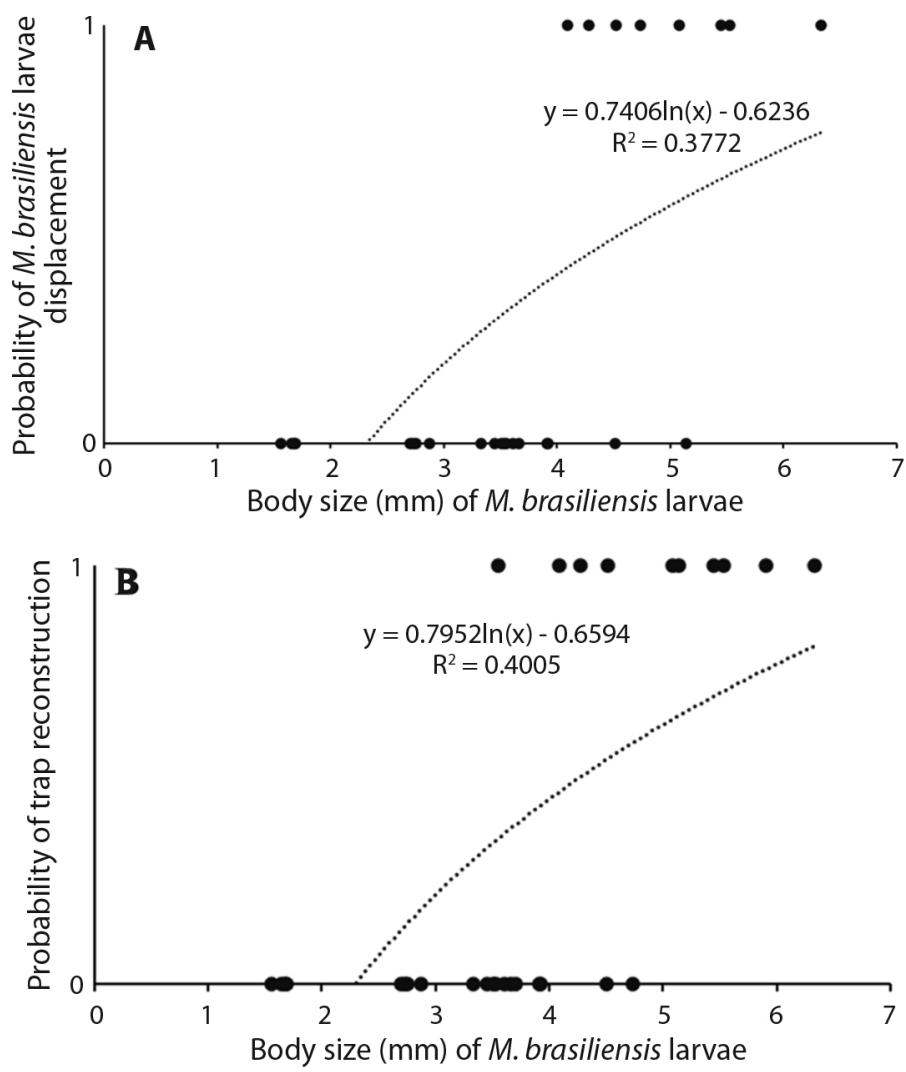

Fig. 2. A. Probability of displacement of traps by M. brasiliensis larvae as function of body size after waterlogging of soil caused by simulation of rainfall. B. Probability of reconstruction of traps by M. brasiliensis larvae as function of body size after waterlogging of soil caused by simulation of rainfall (Second Experiment).

the risk of cannibalism (Lima, 2016; Lucas, 1985). In the present study, more than half (61 $\%)$ of the M. brasiliensis larvae in the natural environment rebuilt their traps at the same site seven days after the simulation of rain, revealing that the larvae remained in the same location, waiting for the soil to dry.

Other studies have also demonstrated that antlion larvae exhibit strong site fidelity for the construction of their traps (Crowley \& Linton, 1999; Lucas, 1985). One of the reasons for this behavior is the selection of a dry, warm micro-habitat, as reported by Miler et al. (2019) for antlions found the tropical forest of Borneo. Moist soil hinders trap building by agglutinating the soil particles and reducing sliding movements between the grains, thereby restricting the movement of the antlion larvae (Devetak et al., 2005; Lucas, 1982). These characteristics lead the trap-building larvae to select dry locations.

In the natural environment, the determination of the location for the rebuilding of traps implies choices regarding the availability of prey items, intraspecific competition, and abiotic factors, such as the granulometry of the soil (Devetak \& Arnett, 2015; Farji-Brener, 2003; Scharf et al., 2008; Scharf \& Ovadia, 2006). In the present study, the M. brasiliensis larvae relocated the traps less in the natural environment compared to the laboratory. This may have been due to the fact that the larvae were alone in the plastic recipients in the laboratory. As these larvae are cannibals 
(Lima, 2016), avoiding relocation to sites close to neighboring larvae could help ensure that the larva does not become prey.

In the study conducted by Lima et al. (2019), larger larvae were found more distant from the clusters in which the oviposition of the adult females occurred, suggesting that larvae of a certain size perform movements with greater frequency. According to Lucas (1985) and Fisher (1989), larger larvae are found more distant from their clusters in response to temperature, as larger antlion larvae are less capable of supporting warmer locations. Studying Myrmeleon uniformis, Faria et al. (1994) found that average trap size was significantly larger in open areas than areas protected from direct sunlight, whereas Scharf et al. (2008) found that Myrmeleon hyalinus in desert environments selected shaded locations and often moved to shaded areas when exposed to the sun.

The laboratory experiment showed that relocation for the rebuilding of new traps occurs as a function of body size in M. brasiliensis, as larger larvae moved their traps more than smaller larvae. The fact that the relocation of larvae is affected by body size may be related to the greater energy storage capability of larger individuals compared to smaller individuals. Lucas (1985) found that the metabolic rates of Myrmeleon carolinus and Myrmeleon crudelis were approximately 10 -fold greater during trap building than during rest. Bearing this metabolic cost likely requires a certain energy reserve, which is more difficult for smaller larvae due to their lower prey capture rate (Nonato \& Lima, 2011). However, other researchers found that small antlions relocated with greater frequency than larger individuals (e.g., Griffiths, 1993), which may suggest a specific response for each species.

When the larvae were exposed to seven days in waterlogged soil with no possibility of relocating to areas with dry soil, the mortality rate was high (52\%). Moreover, the probability of rebuilding the traps after this period was higher among $M$. brasiliensis larvae with a larger body size. Thus, body size was an important variable to enabling the rebuilding of traps after the waterlogging of the soil. However, the rebuilt traps were smaller than those found prior to the disturbance. Variations in trap size occur in response to success in capturing prey and the energy expenditure caused by the disturbance to the trap (Jenkins, 1994; Hauber, 1999; Liang et al., 2010). Thus, besides the high mortality rate, the foraging of M. brasiliensis larvae can also be affected in situations of long periods of waterlogged soil, as the rebuilt trap is smaller and the success of capturing prey items is positively related to trap size (Nonato \& Lima, 2011).

Trap maintenance is important to ensuring antlion larvae access to food. The rebuilding of traps after a disturbance generally occurs on the same or following day (Boake et al., 1984; Eltz, 1997). However, when rain is the disturbing force, the larvae need to wait for the soil to dry before rebuilding, which can take five days in the Cerrado biome (Freire \& Lima, 2019). In the present study, trap rebuilding and relocation was governed by the size of the larvae. Thus, the waterlogging of the soil due to rainfall affects the foraging of M. brasiliensis larvae, which are impeded from rebuilding their traps for a period. In situations of long periods of waterlogged soil, the larvae have a high mortality rate; rebuilding of the traps occurs after the soil dries out, but the traps are smaller. These data suggest that changes in the rainfall pattern can affect the population structure of $M$. brasiliensis larvae, with the selection of larger individuals in situations of more severe rains.

Ethical statement: the authors declare that they all agree with this publication and made significant contributions; that there is no conflict of interest of any kind; and that we followed all pertinent ethical and legal procedures and requirements. All financial sources are fully and clearly stated in the acknowledgements section. A signed document has been filed in the journal archives. 


\section{ACKNOWLEDGMENTS}

This research was developed with the support of the Universidade Federal de Mato Grosso do Sul - UFMS/MEC - Brazil and the Universidade Estadual de Mato Grosso do Sul (UEMS) - Aquidauana.

\section{RESUMEN}

\section{Reconstrucción de trampas por larvas de Myrmeleon brasiliensis (Neuroptera: Myrmeleontidae) tras las inundaciones: efecto del tamaño corporal}

Introducción: Los insectos inmaduros de hormiga león de la especie Myrmeleon brasiliensis (Neuroptera, Myrmeleontidae), construyen trampas en el suelo arenoso seco para capturar a sus presas.

Objetivo: El objetivo de este trabajo fue analizar cómo la inundación del suelo, como la lluvia, afecta al comportamiento de reconstrucción y de desplazamiento de las trampas de $M$. brasiliensis según las diferentes tallas.

Métodos: El estudio fue conducido entre julio y diciembre del 2019. Las larvas fueron observadas y recolectadas en una Reserva Forestal en la ciudad de Aquidauana, Estado de Mato Grosso del Sur, Brasil.

Resultados: Observamos que, en el ambiente natural, siete días después de la lluvia simulada, la mayoría de las larvas reconstruyeron a sus trampas en el mismo sitio y con diámetro más pequeño que el observado antes de la lluvia simulada. En el laboratorio fue observado que después de la inundación del suelo, el desplazamiento de las larvas y la reconstrucción de las trampas es afectado por el tamaño de su cuerpo. Así, larvas de M. brasiliensis más grandes se desplazan más y presentan una probabilidad más grande de reconstruir a sus trampas.

Conclusión: De esa manera, la inundación del suelo afecta el forrajeo de las larvas $M$. brasiliensis, que se quedan impedidas por un tiempo durante la reconstrucción de sus trampas. Además, en situaciones de largos periodos de inundación del suelo, las larvas presentan una alta tasa de mortalidad y la reconstrucción de sus trampas ocurre después que se seca el suelo, pero esas trampas suelen ser más pequeñas. Esos datos sugieren que es posible que variaciones en el patrón de lluvia pueden afectar la estructura poblacional de las larvas $M$. brasiliensis, pues en situaciones de lluvias más fuertes, las larvas más grandes suelen tener más éxito. En este proceso, las larvas más pequeñas se ven más afectadas, ya que se impide su búsqueda de alimento.

Palabras clave: hormiga-león; comportamiento de construcción; forrajeo; Myrmeleontinae; lluvia.

\section{REFERENCES}

Alcock, J. (1972). The evolution of tools by feeding animals. Evolution, 26(3), 464-473.

Boake, C. R. E., Andow, D., \& Visscher, P. K. (1984) Spacing of antlions and their pits. American Midland Naturalist, 111(1), 192-194.

Botz, J. T., Loudon, C., Barger, J. B., Olafssen, J. S., \& Steeples, D. W. (2003). Effects of slope and particle size on ant locomotion: implications for choice of substrate. Journal of the Kansas Entomological Society, 76(3), 426-435.

Burgess, M. G. (2009). Sub-optimal pit construction in predatory ant lion larvae (Myrmeleon sp.). Journal of Theoretical Biology, 260(3), 379-385.

Coutinho, L. M. (2000). O bioma do Cerrado. In A. L. Klein (Ed.), Eugen Warming e o Cerrado brasileiro: um século depois (pp. 77-92). Editora UNESP.

Crowley, P. H., \& Linton, M. C. (1999). Antlion foraging: tracking prey across space and time. Ecology, 80(7), 2271-2282.

Day, M. D., \& Zalucki, M. P. (2000). Effect of density on spatial distribution, pit formation and pit diameter of Myrmeleon acer Walker, (Neuroptera: Myrmeleontidae): patterns and processes. Austral Ecology, 25(1), 58-64.

Devetak, D., \& Arnett, A. E. (2015). Preference of antlion and wormlion larvae (Neuroptera: Myrmeleontidae; Diptera: Vermileonidae) for substrates according to substrate particle sizes. European Journal of Entomo$\log y, 112(3), 500-509$.

Devetak, D., Podlesnik, J., Scharf, I., \& Klenovšek, T. (2020). Fine sand particles enable antlions to build pitfall traps with advanced three-dimensional geometry. Journal of Experimental Biology, 223(15).

Devetak, D., Špernjak, A., \& Janžekovič, F. (2005). Substrate particle size affects pit building decision and pit size in the antlion larvae Euroleon nostras (Neuroptera: Myrmeleontidae). Physiological Entomology, 30(2), 158-163.

Dias, S. C., Santos, B. A., Werneck, F. P., Lira, P. K., Carrasco-Carbadillo, V., \& Fernandes, G. W. (2006). Efficiency of prey subjugation by one species of Myrmeleon larvae (Neuroptera: Myrmeleontidae) in the central Amazonia. Brazilian Journal Biology, 66(2), 441-442.

Eltz, T. (1997). Foraging in the ant-lion Myrmeleon mobilis Hagen 1888 (Neuroptera: Myrmeleontidae): behavioral flexibility of a sit-and-wait predator. Journal of Insect Behavior, 10(1), 1-11. 
Faria, M. L., Prado, P. I. L., Bede, L. C., \& Fernandes, G. W. (1994). Estrutura e dinâmica de uma população de larvas de Myrmeleon uniformis (Neuroptera: Myrmeleontidae). Brazilian Journal Biology, 54(2), $335-344$

Farji-Brener, A. G. (2003). Microhabitat selection by antlion larvae, Myrmeleon crudelis: effect of soil particle size on pit-trap design and capture. Journal of Insect Behavior, 16(3), 783-796.

Fisher, M. (1989). Ant-lion life cycles in Nigeria. Journal of Tropical Ecology, 5(2), 247-250.

Freire, L. G., \& Lima, T. N. (2019). Effect of rain on trap building by Myrmeleon brasiliensis. Entomologia Experimentalis et Applicata, 167(6), 561-565.

Gotelli, N. J. (1993). Ant lion zones causes of high-density predator aggregations. Ecology, 74(1), 226-237.

Griffiths, D. (1980). The feeding biology of ant-lion larvae: prey capture, handling, and utilization. Journal of Animal Ecology, 49(1), 99-125.

Griffiths, D. (1985). Phenology and larval-adult size relations in the antlions Macroleon quinquemaculatus. Journal of Animal Ecology, 54(2), 573-581.

Griffiths, D. (1993). Intraspecific competition in ant-lion (Macroleon quinquemaculatus) larvae in the field. Oecologia, 93(4), 531-537.

Hansell, M. (2007). Built by Animals: The Natural History of Animal Architecture. Oxford University Press.

Hauber, M. E. (1999). Variation in pit size of antlion (Myrmeleon carolinus) larvae: the importance of pit construction. Physiological Entomology, 24(1), 37-40.

Heinrich, B., \& Heinrich, M. J. E. (1984). The pit-trapping foraging strategy of the ant lion, Myrmeleon immaculatus DeGeer (Neuroptera: Myrmeleontidae). Behavioral Ecology and Sociobiology, 14(2), 151-160.

Humeau, A., Rougé, J., \& Casas, J. (2015). Optimal range of prey size for antlions. Ecological Entomology, 40(6), 776-781.

Jenkins, B. A. (1994). The behavioral response of the antlion Myrmeleon pictifrons to a sudden change in prey capture rate. Acta Oecologica, 15(2), 213-240.

Liang, S. H., Lin, W. Y., Lin, Y. C., Chen, Y. C., \& Shieh, B. S. (2010). Variations in the pit size of Cueta sauteri (Neuroptera: Myrmeleontidae) larvae in response to past pit-building experience and food limitation. Zoological Studies, 49(1), 102-107.
Lima, T. N. (2016). Cannibalism among Myrmeleon brasiliensis larvae (Návas, 1914) (Neuroptera, Myrmeleontidae). Acta Scientiarum. Biological Sciences, 38(4), 447-450.

Lima, T. N., \& Faria, R. R. (2007). Seleção de microhabitat por larvas de formiga-leão Myrmeleon brasiliensis (Návas) (Neuroptera: Myrmeleontidae), em uma Reserva Florestal, Aquidauana, MS. Neotropical Entomology, 36(5), 812-814.

Lima, T. L., \& Lopes, F. S. (2016). Effect of density, disturbance and food on displacement of the Myrmeleon brasiliensis (Navás 1914) (Neuroptera, Myrmeleontidae). Ecologia Austral, 26(1), 166-170.

Lima, T. N., Freire, L. G., \& Lima, D. C. A. (2019). Effect of asymmetric competition on distance among Myrmeleon brasiliensis (Návas, 1914) (Neuroptera: Myrmeleontidae) larvae. Acta Scientiarum. Biological Sciences, 41(1), 1-6.

Lima, T. N., \& Silva, D. C. R. (2017). Effect of energetic cost to maintain the trap for Myrmeleon brasiliensis (Neuroptera, Myrmeleontidae) in its development and adult size. Brazilian Journal of Biology, 77(1), $38-42$.

Lucas, J. R. (1982). The biophysics of pit construction by antlion larvae. Animal Behaviour, 30(3), 651-657.

Lucas, J. R. (1985). Metabolic rates and pit-construction costs of two antlion species. Journal of Animal Ecology, 54(1), 295-309.

Miler, K., Yahya, B. E., \& Czarnoleski, M. (2019). Substrate moisture, particle size and temperature preferences of trap-building larvae of sympatric antlions and wormlions from the rainforest of Borneo. Ecological Entomology, 44(4), 488-493.

Missirian, G. B., Uchôa-Fernandes, M. A., \& Fischer, E. (2006). Development of Myrmeleon brasiliensis (Navás) (Neuroptera, Myrmeleontidae), in laboratory, with different natural diets. Revista Brasileira de Zoologia, 23(4), 1044-1050.

Nonato, L. M., \& Lima, T. N. (2011). Comportamiento de depredación de los estadios larvales de Myrmeleon brasiliensis (Neuroptera: Myrmeleontidae). Revista Colombiana de Entomología, 37(1), 354-356.

Ruxton, G. D., \& Hansell, M. H. (2007). Why are pitfall traps so rare in the natural world? Evolutionary Ecology, 23(2), 181-186.

Scharf, I., Hollender, Y., Subach, A., \& Ovadia, O. (2008). Effect of spatial pattern and microhabitat on pit construction and relocation in Myrmeleon hyalinus 
(Neuroptera: Myrmeleontidae) larvae. Ecological Entomology, 33(3), 337-345.

Scharf, I., \& Ovadia, O. (2006). Factors influencing site abandonment and site selection in a sit-and-wait predator: A review of pit-building antlion larvae. Journal of Insect Behavior, 19(2), 197-218.

Simberloff, D., King, L., Dillon, P., Lowries, S., Lorence, D., \& Schilling, E. (1978). Holes in the doughnut theory: the dispersions of ant-lions. Brenesia, 14(15), $13-46$.

Triplehorn, C. A., \& Johnson, N. F. (2005). Borror and delong's introduction to the study of insects ( $7^{\text {th }} \mathrm{Ed}$.). Brooks/Cole Publishing.

Youthed, G. J., \& Moran, V. C. (1969). Pit construction by myrmeleontidae larvae. Journal of Insect Physiology, 15(5), 867-875. 